\title{
Upaya Meningkatkan Hasil Belajar Matematika dengan Menggunakan Aplikasi Google Classroom Siswa Kelas X IPA 1 SMA N 3 Kerinci
}

\author{
Dien Violeta \\ SMAN 3 Kerinci \\ Correspondence email: dienvioleta44@gmail.com
}

\begin{abstract}
Abstrak. Penelitian ini bertujuan untuk meningkatkan hasil belajar peserta didik kelas X MIPA 1 SMA Negeri 3 Kerinci dengan memanfaatkan aplikasi google classroom sebagai salah satu upaya pembelajaran selama pandemi Covid-19 pada materi Trigonometri. Penelitian ini adalah penelitian tindakan kelas yang dilaksanakan selama dua siklus. Setiap siklus terdiri atas tahap perencanaan (planning), tindakan (action), pengamatan (observation), dan refleksi (reflection). Upaya pembelajaran yang digunakan dengan memanfaatkan aplikasi google classroom. Kelebihan dari aplikasi ini adalah dapat mempermudah guru dalam mengelola pembelajaran dan menyampaikan informasi secara tepat dan akurat kepada peserta didik. Hasil dari penelitan ini menunjukkan bahwa upaya pembelajaran dengan memanfaatkan teknologi berupa aplikasi google classroom selama pandemi Covid-19 dapat meningkatkan hasil belajar peserta didik pada materi Trigonometri Kelas X MIPA 1 SMA Negeri 3 Kerinci, Hasil analisis data, ketuntasan hasil belajar matematika pada siklus 1 dengan rata-rata nilai 72 atau $64 \%$, pada siklus 2 menunjukkan peningkatan dengan capaian ketuntasan 84 atau $88 \%$. Hal ini menunjukkan bahwa target persentase ketuntasan peserta didik telah melebihi dari nilai batas minimal. Oleh Karena itu disarankan kepada guru mata pelajaran matematika agar menggunakan teknologi aplikasi google classroom sebagai salah satu solusi untuk mengatasi permasalahan dalam belajar matematika terutama pada materi Trigonometri.
\end{abstract}

Kata kunci: Google Clasroom, pembelajaran, hasil belajar.

\begin{abstract}
This study aims to improve the students' learning achievemetn at grade X MIPA 1, SMAN 3 Kerinci, by using Google classroom platform as one of learning strategies during the Covid-19 pandemic on trigonometry subject. This study is a classroom action research conducted in two cycles. Each cycle consists of planning, action, observation, and reflection. Learning strategies used was the Google classroom platform. The advantage of this platform is learning management became easier for teachers and conveying the information to students could be done precisely and accurately. The results of this study indicated that the learning strategy using Google classroom during Covid-19 pandemic could improve student learning achievement on trigonometry subject at grade X MIPA 1 SMAN 3 Kerinci. The result of data analysis showed that the student's average score in cycle 1 was $72(64 \%)$. It became higher in cycle 2 to $84(88 \%)$. Result of this study described that the target percentage of student completeness has exceeded the minimum standard of achievement. It could be concluded that the implementation of Learning strategies using Google classroom platform improved the student's learning achievement significantly. Therefore, it was suggested to math Teachers to aply the strategy in teaching as the alternative solution particularly in Algebra Trigonometri subject.
\end{abstract}

Keywords: Google Clasroom, Learning, Learning Achievement

\section{PENDAHULUAN}

Dalam Masa Darurat Penyebaran Corona Virus Deseases-19. Menteri Pendidikan dan Kebudayaan mengeluarkan surat edaran Nomor 4 Tahun 2020 tentang Pelaksanaan Kebijakan Pendidikan Agar dapat memutus mata rantai penyebaran virus ini. Pemerintah menganjurkan untuk menutup kegiatan pembelajaran di sekolah dan menerapkan pembelajaran daring (online).

Pembelajaran daring atau yang lebih sering disebut dengan E-learning merupakan pembelajaran berbasis teknologi infomasi yang dilakukan secara online atau tidak dengan tatap muka di kelas. I Made Bhudi Saputra, dkk (2021) mengemukakan murid/siswa adalah pemimpin dalam pemelajaran dalam artian merekalah yang membuat kegiatan belajar mengajar bermakna, sehingga pembelajaran disesuaikan dengan tingkatan kemampuan siswa dan didukung dengan beragam teknologi yang memberikan pendekatan 
Sumarni dan Refinaldi, Internal Locus Of Control, Pemberian Punichment, dan Gaya Belajar Visual terhadap Prestasi Belajar Mahasiswa STKIP Nasional Pariaman

personal bagi kemajuan pemelajaran tiap siswa, tanpa mengabaikan pentingnya aspek sosialisasi dan bekerja dalam kelompok untuk memupuk solidaritas sosial dan keterampilan lunak (soft skill).

Merdeka Belajar merupakan sebuah paket kebijakan dari Kemendikbud untuk meningkatkan kualitas pendidikan di Indonesia. Kebijakan Merdeka belajar ini bisa berjalan dengan maksimal tentunya jika didukung oleh inovasi dan pemanfaatan TIK dalam pembelajaran. Apalagi dalam kondisi pandemi covid 19 seperti saat ini sudah tentu pemanfaatan TIK ini menjadi hal yang wajib dilakukan guna terlaksananya pembelajaran yang berkualitas. Guru dituntut untuk tetap mampu memberikan pelayanan pembelajaran kepada siswa yang sedang belajar di rumah. (http://belajar.kemdikbud.go.id)

Menteri Pendidikan dan Kebudayaan (Mendikbud) No. 4 Tahun 2020 Nadiem Anwar Makarim mengungkapkan, pendekatan belajar dari rumah sebagai langkah strategis pertama pemerintah dalam upaya pencegahan penyebaran Corona Virus Disease (Covid-19) secara luas. Kesehatan dan keselamatan para insan pendidikan menjadi prioritas pemerintah. Ia juga mengatakan bahwa pemanfaatan teknologi dapat diaplikasikan saat melakukan pembelajaran jarak jauh. Sehingga proses pembelajaran tetap dapat dilaksanakan dengan sesuai harapan.

Guru sebagai tenaga pengajar dituntut untuk melakukan inovasi dalam pembelajaran dengan memanfaatkan aplikasi yang telah disediakan pemerintah untuk proses pendidikan. Misalnya saja aplikasi Rumah Belajar, Meja Kita, WeKiddo, hingga Google For Education. Pemerintah juga menyediakan alat konferensi video yang tersedia untuk seluruh pengguna GoogleSuite, dan Google Classroom, untuk mengikuti kelas dan melanjutkan pembelajaran jarak jauh dari rumah. (http://belajar.kemdikbud.go.id)

Penggunaan Google Classroom ini sesungguhnya mempermudah guru dalam mengelola pembelajaran dan menyampaikan informasi secara cepat dan akurat kepada siswa (Hardiyana, 2015). Google Classroom di desain untuk empat pengguna yaitu pengajar, siswa, wali dan administrator. Kelebihan aplikasi Google Classroom dibandingan dengan aplikasi lain yaitu aplikasi Google Classroom dapat digunakan untuk membuat dan mengelola kelas, tugas, nilai serta memberikan masukan secara langsung. Siswa dapat memantau materi dan tugas kelas, berbagi materi dan berinteraksi dalam kelas atau melalui email, mengirim tugas dan mendapatkan masukan nilai secara langsung. Pembelajaran dengan penggunaan Google Classroom ini memiliki kelebihan untuk mempermudah siswa dalam belajar, dengan adanya aplikasi google classroom ini diharapkan mempermudah siswa untuk belajar sehingga dapat meningkatkan hasil belajarnya.

Menurut Chatarina (2006: 5), hasil belajar merupakan perubahan perilaku yang diperoleh pembelajar setelah mengalami aktivitas belajar. Hasil belajar berwujud angka ataupun pernyataan yang mencerminkan tingkat penguasaan materi pelajaran bagi para siswa, yang lebih dikenal dengan prestasi belajar. Belajar meliputi tidak hanya mata pelajaran, tetapi juga penguasaan, kebiasaan, persepsi, kesenangan, minat, penyesuaian soal, bermacam-macam keterampilan, dan cita-cita.

Google classroom adalah aplikasi yang dikembangkan oleh perusahaan google. Dengan adanya aplikasi ini pengajar dan siswa dari sekolah manapun bisa berkomunikasi dengan cara yang jauh lebih sederhana. Salah satu kekuatan google classroom yaitu memungkinkan penghematan kertas karena pekerjaan atau dokumen yang digunakan di kelas akan dibagikan secara digital. selain mudah digunakan di aplikasi google classroom ini menyajikan berbagai macam fitur yang mendukung pada proses kegiatan pembelajaran, seperti membuat salinan dokumen otomatis untk siswa, membuat tugas dan langsung menilainya. Kelebihan aplikasi google classroom dibandingkan dengan aplikasi yang lain yaitu aplikasi google classroom ini bisa diakses secara gratis dan dirancang khusus untuk membantu guru atau pengajar dalam pembelajaran. 
Sumarni dan Refinaldi, Internal Locus Of Control, Pemberian Punichment, dan Gaya Belajar Visual terhadap Prestasi Belajar Mahasiswa STKIP Nasional Pariaman

Menurut Hakim (2016:2) aplikasi Google Classroom merupakan sebuah aplikasi yang memungkinkan ruang kelas di dunia maya. Selain itu google classroom bisa menjadi sarana distribusi tugas, submit tugas bahkan menilai tugas-tugas yang dikumpulkan. Dengan demikian, aplikasi ini dapat membantu memudahkan guru dan siswa dalam melaksanakan proses belajar dengan lebih mendalam. Hal ini disebabkan karena baik siswa maupun guru dapat mengumpulkan tugas, mendistribusikan tugas, menilai tugas di rumah atau dimanapun tanpa terikat batas waktu atau jam pelajaran. Penggunaan aplikasi google classroom dilakukan sebagai media pembelajaran daring selama masa Pandemi Covid-19

Fungsi Google Classroom Pada situs google classroom juga tertulis bahwa terhubung dengan semua layanan google for education yang lainnya, sehingga pendidik dapat memanfaatkan google mail, google drive, google calender, google docs, google sheets, google slides, dan google sites dalam proses pembelajarannya. Sehingga saat pendidik menggunakan google classroom pendidik juga dapat memanfaatkan google calender untuk mengingatkan siswa tentang jadwal atau tugas yang ada, sedangkan penggunaan google drive sebagai tempat untuk menyimpan keperluan pembelajaran seperti power point, file yang perlu digunakan dalam pembelajaran maupun yang lainnya. Dengan demikian google classroom dapat membantu memudahkan guru dan siswa dalam melaksanakan kegiatan belajar mengajar dengan lebih mendalam.

Menurut Janzen M dan Mary dalam Iftakhar (2016:13) menyatakan bahwa kelebihan dari aplikasi Google Classroom antara lain yaitu: 1) Mudah digunakan karena desain google kelas sengaja menyederhanakan antar muka instruksional dan opsi yang digunakan untuk tugas pengiriman dan pelacakan; komunikasi dengan keseluruhan kursus atau individu juga disederhanakan melalui pemberitahuan pengumuman dan email. 2) Menghemat waktu karena ruang kelas google dirancang untuk menghemat waktu dengan mengintegrasikan dan mengotomatisasi penggunaan aplikasi google lainnya, termasuk dokumen, slide, dan spreadsheet, proses pemberian distribusi dokumen, penilaian formatif, dan umpan balik disederhanakan. 3) Berbasis cloud. Google classroom menghadirkan teknologi yang lebih profesional dan otentik untuk digunakan dalam lingkungan belajar karena aplikasi google mewakili sebagian besar alat komunikasi perusahaan berbasis cloud yang digunakan di seluruh angkatan kerja profesional. 4) Fleksibel karena aplikasi ini mudah diakses dan dapat digunakan oleh infrastruktur dan siswa di lingkungan belajar tatap muka dan lingkungan online sepenuhnya.

Hal ini memungkinkan para pendidik untuk mengeksplorasi dan memengaruhi metode pembelajaran yang dibalik lebih mudah serta mengotomatisasi dan mengatur distribusi dan pengumpulan tugas serta komunikasi dengan jangkauan luas. 5) Gratis dikarenakan google kelas sendiri sudah dapat digunakan oleh siapapun untuk membuka kelas asalkan memiliki akun gmail. Selain itu dapat mengakses semua aplikasi lainnya, seperti Drive, Documents, Spreadsheet, Slides, dan lain-lain. Cukup dengan mendaftar ke akun google. 6) Ramah seluler. Itulah mengapa google classroom dirancang agar responsif. Mudah digunakan pada perangkat mobile manapun.

Akses mobile ke materi pembelajaran yang menarik dan mudah untuk berinteraksi sangat penting dalam lingkungan belajar terhubung web saat ini. Pemahaman konsep matematika penting dilakukan agar nantinya siswa mampu mengaplikasikan dalam kehidupan sehari-hari yang disesuaikan dengan pengalaman nyata. Banyak siswa yang beranggapan bahwa matematika merupakan mata pelajaran yang sulit dan rumit, oleh karena itu memerlukan kesungguhan agar siswa benar-benar menguasi matematika.

Kesulitan belajar matematika yang dialami oleh siswa kelas X MIPA 1 Berdasarkan hasil observasi yang peneliti lakukan terhadap siswa yang hasil belajarnya rendah, diperoleh informasi bahwa rendahnya pemahaman siswa dalam memahami materi yang disampaikan guru, karena tidak jelasnya instruksi ataupun 
Sumarni dan Refinaldi, Internal Locus Of Control, Pemberian Punichment, dan Gaya Belajar Visual terhadap Prestasi Belajar Mahasiswa STKIP Nasional Pariaman

informasi yang diperoleh di grup belajar daring siswa sehingga hasil belajar matematika yang diperoleh siswa rendah. Dari 25 orang siswa dalam satu kelas terdapat 20 orang siswa belum mencapai Kriteria Ketuntasan Minimum (KKM) yaitu 70. Ada beberapa faktor yang menyebabkan siswa belum mencapai KKM mata pelajaran matematika yaitu belum optimal dalam pemanfaatan baik media maupun sistem pembelajaran daring (online).

Media pembelajaran yang digunakan sebelumnya yaitu media Whatsapp Group, dengan menggunakan media pembelajaran ini, siswa merasa kesulitan mendapatakan penjelasan tentang materi yang disampaikan oleh guru, sehingga tugas yang di harapkan oleh guru di kumpulkan siswa tidak sesuai dengan yang diharapkan oleh guru, dalam rekapan tugas guru juga mengalami kendala dalam pengecekan tugas siswa dan tidak rapi dalam penyusunan administrasi mengajar guru.

Keberhasilan belajar matematika juga sangat dipengaruhi oleh peran guru dalam proses pembelajaran. Upaya untuk menunjang keberhasilan pembelajaran adalah dengan digunakannya pendekatan, model atau metode pembelajaran maupun media pembelajaran yang menarik sesuai dengan karakteristik siswa dan mata pelajaran matematika itu sendiri.

Menyikapi kondisi stay at home sebagai dampak pandemi Covid-19, guru dituntut untuk mampu menyajikan pembelajaran secara daring (dalam jaringan) dengan memanfaatkan teknologi. Pembelajaran saat ini lebih diarahkan pada aktivitas modernisasi dengan memanfaatkan teknologi canggih dengan harapan dapat membantu peserta didik dalam menerima mata pelajaran, khususnya materi Trigonometri secara konstektual, kreatif, interaktif, produktif, inspiratif, efektif, efisien, dan menyenangkan sehingga dapat meningkatkan hasil belajar pada peserta didik.

Menurut Keengwe \& Georgina (2012) dalam penelitiannya menyatakan bahwa perkembangan teknologi yang semakin canggih dapat memberikan perubahan terhadap proses pengajaran dan pembelajaran di sekolah. Internet yang semakin luas dan mudah diakses oleh siapa saja sehingga dapat digunakan sebagai alat dan sarana untuk mempermudah dalam pembelajaran selama pandemi Covid-19.

Pembelajaran berbasis daring (online) dibutuhkan sebagai sarana atau alat untuk mendukung proses pembelajaran selama pandemi Covid-19. Salah satu media teknologi yang sering digunakan saat ini adalah aplikasi pada telepon genggam/ponsel.

Berbagai macam media pembelajaran yang sudah ada namun guru belum memanfaatkan secara maksimal. Salah satunya adalah penggunaan media aplikasi google classroom dapat dimanfaatkan sebagai media pembelajaran untuk membantu meningkatkan hasil belajar peserta didik.

Salah satu media pembelajaran yang dapat dimanfaatkan oleh guru Matematika SMA Negeri 3 Kerinci kelas X MIPA 1 selama pandemi Covid-19 untuk belajar di rumah adalah memanfaatkan e-learning dengan aplikasi yang digunakan berupa Google Classroom.

Dalam proses pembelajaran, peserta didik diberikan penugasan oleh guru dan mengirimkan hasil laporannya ke aplikasi google classroom. Selain itu, peserta didik diberikan materi yang lebih lengkap oleh guru. Selanjutnya guru memberi tugas dan soal sebagai respon dari pembelajaran yang sudah dilakukan di rumah.

Kelebihan dari aplikasi Google Classroom dibandingan dengan aplikasi lain yaitu aplikasi Google Classroom dapat digunakan untuk membuat dan mengelola kelas, tugas, nilai serta memberikan masukan secara langsung. Peserta didik dapat memantau materi dan tugas kelas, berbagi materi dan berinteraksi dalam kelas atau melalui email, mengirim tugas dan mendapatkan masukan nilai secara langsung.

Hal ini sejalan dengan pendapat Hakim (2016) bahwa penggunaan google classroom dapat mempermudah guru dalam mengelola pembelajaran dan menyampaikan informasi secara tepat dan akurat 
Sumarni dan Refinaldi, Internal Locus Of Control, Pemberian Punichment, dan Gaya Belajar Visual terhadap Prestasi Belajar Mahasiswa STKIP Nasional Pariaman

kepada peserta didik. Dengan adanya aplikasi google classroom ini diharapakan mempermudah peserta didik untuk belajar mandiri sehingga dapat meningkatkan hasil belajarnya. Strategi pembelajaran yang baru dan inovatif dengan memanfaatkan aplikasi google classroom dirasa dapat menumbukan rasa semangat belajar peserta didik dan memberikan pengalaman yang baru saat mengikuti kegiatan belajar selama pandemi Covid-19.

Aplikasi baru yang dirasakan bagi peserta didik dapat menambah wawasan dalam menggali kemampuan di bidang teknologi sehingga memberikan rasa percaya diri pada peserta didik. Keunggulan lain dari aplikasi google classroom adalah dapat menampilkan skor secara langsung.

Peserta didik tertarik pada aplikasi ini karena dapat menampilkan hasil skor yang dicapai pada saat menyerahkan pekejaan atau tes yang sehingga memberikan semangat belajar, hal ini dapat mempengaruhi hasil belajar pada peserta didik.

Hasil belajar peserta didik berperan penting dalam proses pembelajaran. Menurut Hamalik dalam Eka warna (2010) Hasil belajar adalah perubahan tingkah laku pada diri siswa, yang dapat diamati dan di ukur dalam bentuk perubahan pengetahuan, sikap, dan keterampilan. Selanjutnya Menurut Kayatun (2014) hasil belajar merupakan hasil yang diperoleh peserta didik setelah terjadinya proses pembelajaran yang ditunjukkan dengan nilai respon penugasan/tes yang diberikan oleh guru setiap materi pembelajaran pada satu pokok bahasan. Berdasarkan permasalahan di atas, bahwa hasil belajar peserta didik selama pandemi Covid-19 sangat penting dalam pembelajaran matematika. Untuk itu perlu strategi dalam pembelajaran matematika saat stay at home salah satu strategi pembelajaran untuk meningkatkan hasil belajar peserta didik dengan memanfaatkan aplikasi Google Classroom selama pandemi Covid-19.

Dengan demikian, tujuan dari penelitian ini adalah untuk mengetahui apakah penggunaan aplikasi google classroom ini dapat meningkatkan hasil belajar matematika siswa. Hasil penelitian ini juga dapat diketahui hasil peningkatan kemampuan melalui tes yang diberikan. Adapun rumusan masalah penelitian adalah bagaimana penggunaan aplikasi google classroom dapat meningkatkan hasil belajar siswa.

\section{METODE PENELITIAN}

Jenis penelitian yang digunakan dalam penelitian ini adalah penelitian tindakan kelas (PTK). Penelitian ini menggunakan 2 siklus dengan beberapa tahapan yaitu tahap perencanaan, pelaksanaan, observasi, dan refleksi. Penelitian ini digunakan untuk mengetahui peningkatan hasil belajar Matematika peserta didik dengan memanfaatkan aplikasi google classroom yang dilakukan selama pandemi Covid-19. Subjek Penelitian ini adalah seluruh siswa kelas X MIPA 1, yang berjumlah 25 Orang yang terdiri dari 14 siswa Laki-laki dan 11 siswa perempuan. Sumber Data Penelitian berasal dari Kelas Maya (Google Classroom, Peserta didik Kelas X MIPA 1 dan Hasil Belajar siswa.

Penelitian ini merupakan penelitian tindakan kelas yang dilaksanakan dalam dua siklus adapun tahapan-tahapannya adalah sebagai berikut:

1. Perencanaan

Pada Tahap Perencanaan dilakukan persiapan yang berhubungan dengan pelaksanaan seperti identifikasi masalah, pembuatan rencana pembelajaran, Pembuatan lembar pengamatan siswa dan guru, Penyusunan Angket siswa.

\section{Pelaksanaan}

Peneliti memanfaatkan google classroom sebagai proyek dalam melakukan kegiatan pembelajaran yaitu, membuat forum diskusi di aplikasi google classroom, pembuatan tugas dan hasilnya akan ditampilkan langsung pada aplikasi google classroom, presentasi kelompok, dan mengerjakan soal test. Soal test ini sebagai nilai hasil belajar pada siklus I dan siklus II yang sebelumnya sudah disampaikan 
Sumarni dan Refinaldi, Internal Locus Of Control, Pemberian Punichment, dan Gaya Belajar Visual terhadap Prestasi Belajar Mahasiswa STKIP Nasional Pariaman

pada pertemuan sebelumnya. Tes diberikan dua kali yaitu pada siklus 1 dan siklus 2 untuk mengidentifikasi perubahan hasil belajar siswa. Hasil belajar dilihat dari pencapaian siswa terhadap kriteria ketuntasan minimal $(\mathrm{KKM} \geq 70)$.

\section{Pengamatan}

Pengamatan adalah suatu kegiatan mengamati jalannya pelaksanaan tindakan untuk memantau sejauhmana keefektifan pembelajaran dengan menggunakan aplikasi google classroom. Siswa diharapkan mampu memanfaatkan aplikasi Google Classroom untuk belajar.

\section{Refleksi}

Dengan data observasi dan angket penelitian, berdasarkan tindakan peneliti dapat direfleksi apakah dengan penggunaan aplikasi google classroom dapat meningkatkan hasil belajar siswa. Hasil dari refleksi akan diadakan perbaikan terhadap perencanaan yang telah dilaksanakan, yang akan digunakan untuk memperbaiki kinerja guru pada siklus berikutnya.

Peneliti ini menggunakan data kualitatif, yaitu data yang berbentuk kata, kalimat, dan skema. Pengumpulan data dilakukan secara sistematis dan data yang dikumpulkan sesuai dengan masalah yang diteliti. Data lapangan dikumpulkan melalui: (1) Observasi (2) Dokumentasi dan (3) Tes. Data yang terkumpul berupa hasil angket, observasi, hasil belajar, data yang diperoleh di analisis secara deskriptif untuk mengetahui pelaksanaan dan hambatan yang terjadi selama pembelajaran. Tahapan-tahapan dalam proses analisis data adalah sebagai berikut:

\section{Reduksi Data}

Reduksi data dalam penelitian ini merupakan proses penyeleksian dan penyederhanaan data melalui seleksi, pemfokusan dan pengabstrakan data mentah ke pola yang lebih terarah dan dikelompokkan berdasarkan kepentingan pada rumusan masalah.

2. Penyajian Data

Penyajian data dilakukan dalam rangka penyusunan informasi secara sistematis mulai dari perencanaan, pelaksanaan, refleksi pada masing siklus.

3. Penarikan kesimpulan adalah pemberian makna pada data yang diperoleh dari penyajian data. Penarikan kesimpulan dilakukan berdasarkan hasil dari semua data yang diperoleh.

Adapun secara lebih rinci analisis datanya adalah sebagai berikut:

a. Analisis data hasil observasi untuk mengetahui proses pelaksanaan pembelajaran siswa

Skala yang digunakan adalah lembar observasi mengunakan skala Guttman, observer membubuhkan tanda cek $(\vee)$ pada langkah-langkah pembelajaran yang terlaksana pada kolom "ya" dan "tidak" dan dari setiap aspek yang terlaksana (pada kolom "ya"), diberi skor 1, jika tidak terlaksana (pada kolom "tidak") diberi skor 0

Kemudian dihitung persentase keterlaksanaanya dengan rumus:

$$
P=\frac{F}{A} \quad x 100 \%
$$

Keterangan :

$\mathrm{P}=$ Persentase keterlaksanaan Pembelajaran

$\mathrm{F}=$ Jumlah Skor Keterlaksanaan Pembelajaran

A = Jumlah Skor Maksimal Keterlaksanaan Pembelajaran 
Sumarni dan Refinaldi, Internal Locus Of Control, Pemberian Punichment, dan Gaya Belajar Visual terhadap Prestasi Belajar Mahasiswa STKIP Nasional Pariaman

b. Analisa data yang digunakan dalam teknik ini adalah teknik deskriptif bertujuan untuk mendeskripsikan tentang hasil belajar siswa secara individual Ketuntasan individual tercapai jika $70 \%$ dengan rumus:

$$
S=\frac{R}{N} \times 100 \%
$$

Keterangan :

$\mathrm{S}=$ Persentase Ketuntasan Individual

$\mathrm{R}=$ Skor yang diperoleh

$\mathrm{N}=$ Skor Maksimal

c. Analisa data yang digunakan dalam teknik ini adalah teknik deskriptif bertujuan untuk mendeskripsikan tentang hasil belajar siswa secara klasikal.

Ketuntasan Klasikal tercapai jika 75\% dengan rumus:

$$
P K=\frac{J T}{J S} \times 100 \%
$$

Keterangan :

PK $=$ Persentase ketuntasan klasikal

$\mathrm{JT}=$ Jumlah Siswa yang tuntas

$\mathrm{JS}=$ Jumlah seluruh siswa

Ketuntasan Klasikal tercapai jika 75\%

\section{HASIL DAN PEMBAHASAN}

Hasil

Penelitian tindakan kelas ini dilaksanakan di kelas X MIPA 1 SMA Negeri 3 Kerinci, Kecamatan Keliling Danau, Kabupaten Kerinci. Penelitian tindakan kelas ini dilakukan dalam 2 siklus untuk menentukan bagaimana cara meningkatkan hasil belajar melalui Pendekatan Pembelajaran Daring berbasis teknologi (aplikasi Google classroom)

Untuk menyiasati ketidak kondusifan di situasi seperti ini, metode daring berbasis teknologi bisa dijadikan salah satu hal yang cukup efektif untuk melaksanakan pembelajaran Matematika bagi siswa kelas X MIPA 1 SMA Negeri 3 Kerinci.

Berdasarkan hasil observasi yang dilaksanakan, mulai dari pemeriksaan tahap studi awal sampai pada siklus kedua diperoleh data sebagai berikut:

\section{Pra Siklus}

Tahap Studi Awal data yang diperoleh dari hasil observasi menunjukkan beberapa siswa mendapatkan nilai Matematika belum memenuhi standar Kriteria Ketuntasan Minimal (KKM) Matematika yang ditetapkan di SMA Negeri 3 Kerinci yaitu 70. Peneliti melakukan observasi terhadap proses pembelajaran pada saat pembelajaran matematika dengan menggunakan lembar observasi, dengan pokok bahasan memahami Trigonometri. 
Sumarni dan Refinaldi, Internal Locus Of Control, Pemberian Punichment, dan Gaya Belajar Visual terhadap Prestasi Belajar Mahasiswa STKIP Nasional Pariaman

Dari hasil observasi tahap awal yang dilakukan pada tanggal 25 Januari 2021 diperoleh gambaran, Pembelajaran masih berpusat pada guru, guru lebih aktif dalam pembelajaran., pendekatan dalam pembelajaran yang digunakan oleh guru kurang variatif, pendekatan yang digunakan lebih kepada pemberian informasi terkesan menoton bagi siswa, siswa tidak melibatkan diri selama pembelajaran daring, siswa masih enggan untuk menyampaikan pendapat atau bertanya kepada guru jika belum memahami materi, saat mengerjakan tugas individu, siswa masih tampak kurang bersungguh-sungguh dan seringkali menanyakan jawaban kepada siswa lain.

Berdasarkan uraian tersebut dapat disimpulkan bahwa permasalahan yang dihadapi oleh guru dalam pembelajaran Matematika adalah kurangnya pemahaman siswa dalam memahami materi pembelajaran, upaya pembelajaran kurang efektif sehingga berdampak pada rendahnya hasil belajar yang diperoleh siswa.

Tabel 1.

Tingkat Ketuntasan Hasil Belajar Pra Siklus Rentang Kategori Pra Siklus

\begin{tabular}{|c|c|c|c|c|}
\hline \multirow{2}{*}{ Rentang } & \multirow{2}{*}{ Kategori } & \multicolumn{2}{|c|}{ Pra Siklus } & \multirow{2}{*}{ Keterangan } \\
\cline { 2 - 4 } & & Frekuensi & Presentase & \\
\hline $86-100$ & Tinggi & $\mathbf{0}$ & $\mathbf{0 \%}$ & \multirow{2}{*}{ Tuntas } \\
\hline $70-85$ & Sedang & $\mathbf{1 2}$ & $\mathbf{4 8 \%}$ & \multirow{2}{*}{ Tidak } \\
& Rendah & $\mathbf{1 3}$ & $\mathbf{5 2 \%}$ & \\
\hline $56-69$ & Sangat Rendah & $\mathbf{0}$ & $\mathbf{0 \%}$ & \\
\hline$\leq 55$ & Total & $\mathbf{2 5}$ & $\mathbf{1 0 0 \%}$ & \\
\hline & Nilai Max & & $\mathbf{8 5}$ & \\
\hline Nilai Min & & $\mathbf{4 5}$ & \\
\hline & Rata-rata & & $\mathbf{6 5}$ & \\
\hline & KKM & & & \\
\hline
\end{tabular}

Dari tabel 4.1 di atas tergambar siswa yang mencapai ketuntasan belajar KKM 70 sebanyak 12 orang siswa dengan persentase (48\%), dan siswa yang belum mencapai ketuntasan belajar kurang dari KKM 70 sebanyak 13 siswa dengan persentase (52\%). Rendahnya skor rata-rata kelas yang hanya mencapai 65 . Dan tingkat ketidak ketuntasan belajar yang mencapai 52\% tersebut, maka peneliti merasa perlu melakukan tindakan untuk mengatasi permasalahan tersebut, peneliti berusaha melakukan tindakan dengan mencoba menerapkan pendekatan pembelajaran Matematika secara daring yaitu dengan metode belajar berbasis teknologi melaksanakan kegiatan pembelajaran secara daring sehingga akan meningkatkan pemahaman siswa terhadap materi pelajaran, meningkatkan keaktifan siswa serta hasil belajar siswa. 
Sumarni dan Refinaldi, Internal Locus Of Control, Pemberian Punichment, dan Gaya Belajar Visual terhadap Prestasi Belajar Mahasiswa STKIP Nasional Pariaman

\section{Siklus I}

Pada siklus ada beberapa yang perlu ditingkatkan oleh guru pada pembelajaran daring berbasis teknologi untuk meningkatkan belajar siswa, peneliti merasa perlu mengaktifkan beberapa aplikasi berbasis teknologi yang dapat mendukung pembelajaran daring berlangsung.

Untuk mengoptimalkan pelaksanaan perbaikan pembelajaraan pada siklus I, maka disusun perencanaan sebagai berikut: 1) Menyusun RPP dengan memperhatikan kekurangan pembelajaran pada pra siklus. 2) Menyiapkan media pembelajaran 3) Menyiapkan lembar observasi. 4) Menentukan pelaksanaan observasi. 5) Menyiapkan alat evaluasi (soal Post test siklus 1)

Pelaksanaan perbaikan pembelajaran pada siklus I dalam pembelajaran daring, masih kurangnya keterlibatan siswa dalam pembelajaran daring, guru belum memberikan instruksi yang jelas dalam kegiatan pembelajaran sehingga tidak semua siswa aktif mengikuti pembelajaran dengan menggunakan aplikasi google classroom dan berdampak pada rendahnya kemampuan siswa dalam memahami materi yang disampaikan guru serta hasil belajar yang diperoleh masih rendah. capaian hasil belajar menunjukkan hasil belum mencapai target, dapat dilihat pada tabel berikut ini:

Tabel 2.

Tingkat Ketuntasan Hasil Belajar Siklus 1 Rentang Kategori Siklus 1

\begin{tabular}{|c|c|c|c|c|}
\hline \multirow{2}{*}{ Rentang } & \multirow{2}{*}{ Kategori } & \multicolumn{2}{|c|}{ Pra Siklus } & \multirow{2}{*}{ Keterangan } \\
\cline { 2 - 4 } & & Frekuensi & Presentase & \\
\hline $86-100$ & Tinggi & $\mathbf{9}$ & $\mathbf{3 6 \%}$ & \multirow{2}{*}{ Tuntas } \\
\hline $70-85$ & Sedang & $\mathbf{7}$ & $\mathbf{2 8 \%}$ & \multirow{2}{*}{$\begin{array}{c}\text { Tidak } \\
\text { tuntas }\end{array}$} \\
\hline $56-69$ & Rendah & $\mathbf{9}$ & $\mathbf{3 6 \%}$ & \\
\hline$\leq 55$ & Sangat Rendah & $\mathbf{0}$ & $\mathbf{0 \%}$ & \\
\hline & Total & $\mathbf{2 5}$ & $\mathbf{1 0 0 \%}$ & \\
\hline & Nilai Max & & $\mathbf{9 0}$ & \\
\hline & Nilai Min & & $\mathbf{7 2}$ \\
\hline & Rata-rata & & $\mathbf{7 0}$ \\
\hline
\end{tabular}

Sumber: Data Hasil Tes Siklus 1

Dari tabel 4.2 diperoleh data siswa yang mencapai ketuntasan belajar KKM 70 sebanyak 16 orang siswa dengan persentase (64\%), dan siswa yang belum mencapai ketuntasan belajar kurang dari KKM 70 sebanyak 9 orang siswa dengan persentase (36\%). Perolehan skor rata-rata ketuntasan siswa baru mencapai 
Sumarni dan Refinaldi, Internal Locus Of Control, Pemberian Punichment, dan Gaya Belajar Visual terhadap Prestasi Belajar Mahasiswa STKIP Nasional Pariaman

72. Terdapat peningkatan hasil belajar siswa pada siklus 1, namun belum mencapai ketuntasan belajar yang diharapkan.

\section{Siklus 2}

Berdasarkan hasil penelitian pada siklus 1 belum menunjukkan peningkatan hasil yang signifikan, peneliti merasa perlu adanya tindakan lebih lanjut, peneliti berusaha dengan mencoba menerapkan pendekatan pembelajaran Matematika secara daring dengan mengkombinasikan metode belajar berbasis teknologi, dalam aplikasi pembelajaran daring yang digunakan sehingga akan lebih meningkatkan pemahaman siswa terhadap materi pelajaran, serta hasil belajar siswa.

Setelah adanya tindakan menunjukkan adanya peningkatan yang signifikan pada persentase hasil belajar siswa dapat dilihat pad tabel berikut ini:

Tabel 3.

Tingkat Ketuntasan Hasil Belajar Siklus 2 Rentang Kategori Siklus 2

\begin{tabular}{|c|c|c|c|c|}
\hline \multirow{2}{*}{ Rentang } & \multirow{2}{*}{ Kategori } & \multicolumn{2}{|c|}{ Pra Siklus } & \multirow{2}{*}{ Keterangan } \\
\cline { 2 - 4 } & & Frekuensi & Presentase & \\
\hline $86-100$ & Tinggi & $\mathbf{1 1}$ & $\mathbf{4 4 \%}$ & \multirow{2}{*}{ Tuntas } \\
\hline $70-85$ & Sedang & $\mathbf{1 1}$ & $\mathbf{4 4 \%}$ & \multirow{2}{*}{$\begin{array}{c}\text { Tidak } \\
\text { tuntas }\end{array}$} \\
\hline $56-69$ & Rendah & $\mathbf{3}$ & $\mathbf{1 2 \%}$ & \\
\hline$\leq 55$ & Sangat Rendah & $\mathbf{0}$ & $\mathbf{0 \%}$ & \\
\hline & Total & $\mathbf{2 5}$ & $\mathbf{1 0 0 \%}$ & \\
\hline Nilai Max & & $\mathbf{9 5}$ & \\
\hline Nilai Min & & $\mathbf{6 8}$ & \\
\hline Rata-rata & & $\mathbf{8 4}$ & \\
\hline & KKM & & & \\
\hline
\end{tabular}

Sumber: Data Hasil Tes Siklus 2

Dari tabel 4.3 diperoleh data siswa yang mencapai ketuntasan belajar KKM 70 sebanyak 22 orang siswa dengan persentase (88\%), dan siswa yang belum mencapai ketuntasan belajar kurang dari KKM 70 sebanyak 3 orang siswa dengan persentase (12\%). Perolehan skor rata-rata ketuntasan siswa mencapai 84. Pada siklus 2 terjadi peningkatan yang signifikan terhadap hasil belajar siswa. Berdasarkan capai yang diperoleh dapat disimpulkan bahwa penggunaan aplikasi google classroom dapat meningkatkan hasil belajar siswa. 


\section{Pembahasan}

\section{Pra Siklus}

Pada kegiatan Pra siklus skor rata-rata kelas yang diperoleh siswa baru dicapai 65. siswa yang mencapai ketuntasan belajar KKM 70 sebanyak 12 orang siswa dengan persentase (48\%), Perolehan skor rata-rata ketuntasan belajar baru mencapai 65. Dari hasil observasi kegiatan prasiklus, maka akan dilaksanakan tindakan dengan penerapan pembelajaran dengan menggunakan aplikasi google classroom.

\section{Siklus 1}

Dari hasil postest, siswa yang mencapai ketuntasan belajar KKM 70 sebanyak 16 orang siswa dengan persentase (64\%), dan siswa yang belum mencapai ketuntasan belajar kurang dari KKM sebanyak 9 orang siswa dengan persentase (36\%). Perolehan skor rata-rata ketuntasan siswa baru mencapai 64. Terdapat peningkatan hasil belajar siswa pada siklus 1, namun belum mencapai ketuntasan belajar yang diharapkan.

\section{Siklus 2}

Pada Siklus 2 siswa yang mencapai ketuntasan belajar pada KKM 70 sebanyak 22 orang siswa dengan persentase (88\%), dan siswa yang belum mencapai ketuntasan belajar kurang dari KKM 70 sebanyak 3 orang siswa dengan persentase (12\%). Perolehan skor rata-rata ketuntasan siswa mencapai 84 . Pada siklus 2 terjadi peningkatan yang signifikan terhadap hasil belajar siswa. Berdasarkan capai yang diperoleh dapat disimpulkan bahwa penggunaan aplikasi google classroom dapat meningkatkan hasil belajar siswa.

\section{KESIMPULAN}

Berdasarkan hasil penelitian dan pembahasan dapat disimpulkan bahwa pemanfaatan aplikasi google classroom pada pembelajaran berbasis daring pada siswa kelas X MIPA 1 SMA Negeri 3 Kerinci. Hal ini dibuktikan dengan adanya peningkatan hasil belajar siswa dari pra siklus baru mencapai rata-rata ketuntasan belajar 65 dengan persentase 48\%. Pada siklus 1 meningkat dengan rata-rata 72, Pada siklus 2 terjadi peningkatan yang signifikan menjadi 88 . Persentase ketuntasan belajar juga meningkat $24 \%$ dari siklus 1 sebesar $64 \%$ menjadi $88 \%$ pada siklus 2 .

Berdasarkan hasil persentase, terjadi peningkatan hasil belajar matematika siswa yang signifikan dan telah mencapai target, sehingga peneliti menghentikan siklusnya dan disarankan kepada guru mata pelajaran matematika agar menggunakan aplikasi google classroom, untuk keefektifan pembelajaran.

\section{DAFTAR PUSTAKA}

Anni, Chatarina tri,dkk. (2006) Psikologi Belajar. Semarang: Universitas Negeri Semarang.

Eka Warna. (2010). Penelitian Tindakan Kelas. Jakarta: Gaung Persada.

Hakim, Abdul Barir. (2016). Efektivitas Penggunaan E-Learning moodle, Google Classroom dan Edmodo Jurnal: I - Statement. Vol. 02 No. I.

Hardiyana, Andri. (2015). Implementasi Google Classroom sebagai Alternatif dalam Meningkatkan Mutu Pembelajaran di Sekolah. Karya Tulis Ilmiah, Cirebon: SMA Negeri 1 Losari.

Iftakhar, Shampa. (2016). “Google Classroom: What Works an How?". Journal of Education and Social Sciences. Vol 3.

I Made Bhudi Saputra, dkk. (2021). Modul 01 Merdeka Belajar Bersama rumah belajar. Jakarta: Kemendikbud 
Sumarni dan Refinaldi, Internal Locus Of Control, Pemberian Punichment, dan Gaya Belajar Visual terhadap Prestasi Belajar Mahasiswa STKIP Nasional Pariaman

Kayatun, Sri. (2014). "Penggunaan Metode Kerja Kelompok untuk Meningkatkan Hasil Belajar Matematika Sekolah Dasar." Jurnal Pendidikan dan Pembelajaran, Volume 3, Nomer 4, April 2014.

Keengwe, J., \& Georgina, D. (2012). The digital course training workshop for online learning and teaching.

Education and Information Technologies, 17(4), 365-379. https://doi.org/10.1007/s10639-011-9164-

Mendikbud No 4 (2020). Pelaksanaan Kebijakan Pendidikan dalam masa darurat Covid 19. Rumah Belajar :http://belajar.kemendikbud.go.id 